УДК 343.81
Denysova T. A.,

Doctor of Sciences (Law), Professor an Assistant of the President for Science and Methodology, Academy of the State Penitentiary Service Honored Lawyer of Ukraine;

Krykushenko O. H.,

Ph.D. in Law, Chief of the Administration of the State Criminal and Executive Service of Ukraine, Major General of Internal Service Honored Lawyer of Ukraine

\title{
CURRENT PROBLEMS OF LABOR USE OF CONVICTS SENTENCED TO IMPRISONMENT
}

The main issues of legal regulation of labor in the history of the development of penal institutions (correctional colonies), its place in the system of basic means of correction and re-socialization are considered by the authors. The problems that arise when the convicts are involved in socially useful work in the modern conditions of functioning of the enterprises of correctional colonies, are determined. Attention is drawn to the need to study foreign experience of involving convicts in labor, as there is a significant economic benefit and educational and corrective effect. The ways of improving the efficiency of labor use of convicts in Ukraine on the basis of voluntariness, development and expansion of the limits of convicts' professional orientation, creating of productive workshops, are indicated.

Key words: convicts, punitive and corrective influence, labor, punishment.

Target setting. One of the main tasks of punishment is convicts' correction and re-socialization, as defined in Art. 6 of the Criminal Executive Code of Ukraine (further - the CEC). In particular, part 3 of the CEC of Ukraine states: «The main means of convicts' correction and re-socialization are the established procedure of execution and serving the punishment (regime), probation, socially 
useful labor, social and educational work, general and vocational studying, public influence $\ll^{1}$.

The history of formation and development of the Criminal and Executive System of Ukraine is inextricably linked with the development of criminal and executive legislation in general and the regulation of criminal and executive legal relations. One of the central places in this process take the issues of the use and regulation of convicts' work. Although, as it was mentioned, work takes a special place among the measures of correctional influence on the convicts. Until now there are such discussions: does really forced labor in Ukrainian prisons, bring any correction to the convicts? must labor be forced, or it should be based on voluntariness? how justified is the imposition of penalties for the rejection to make any socially useful labor? These and other questions are connected with the problems related to the equipment of industrial objects of penal institutions (further - PI). There is no harmony in the approaches, especially among practitioners, regarding the use of professions that convicts had before their moving to the PI and the acquirement of new skills that are often not demanded by modern industries.

Actual scientific researches and issues analysis. It is worth saying that at the territory of independent Ukraine such scholars as: K. A. Avtukhov, I. H. Bohatyrov， T. A. Denysova， O. M. Dzhuzha, V. M. Dromin, O. H. Kolb, V. Ya. Konopelskyi, I. M. Kopotun, O. H. Krykushenko, V. O. Merkulova, H. O. Radov, A. Kh. Stepaniuk, V. M. Trubnykov, V. V. Shablystyi, Yu. V. Shynkarov, I. S. Yakovets and others were working and are working successfully over the problems of Criminal and Executive Law. According to them, based on constitutional guidelines, everyone has the right to work in conditions that meet the requirements of safety and hygiene, to get pay for work without any discrimination of its size, as well as the right to leave, to be protected against unemployment, etc. It should be pointed out that although a legislator's view at in-

${ }^{1}$ Кримінально-виконавчий кодекс України. Офіційний текст. Вид.: «ПАЛИВОДА А. В.». Київ, 
volving convicts to work as at a means of influencing convicts' behaviour is constant, researchers and practitioners are still investigating this issue.

The purpose of the article is to identify the existing problems of labor use of convicts while their serving sentence in form of imprisonment, and also to propose the ways of involving convicts in socially useful work on the basis of the European model, relying on historical experience, analysis of the current criminal and executive legislation, practice of its application and the results of general theoretical studies.

The statement of basic materials. A well-known saying is «Labor is the basic condition of human existence». In Ukraine (at first as a component of tsarist Russia, then the USSR, now as an independent state), the issue of labor use of convicts has always arisen. But at all times, scholars, progressive political figures, and writers voiced their support for the urgent need to change the existing system of involving convicts to work in order the period of convicts' staying in prisons corrects a person with punishment, rather than neglects it, cultivating a faulty state of hard poorly qualified, but more precisely slavish labor.

The disadvantages of Penal System can be defined by the slogan from Dante's Divine Comedy, where, in the part the «Hell», it was talked about the hellish gates topped with the inscription: «Lasciate ogni speranza voi ch'entrate» leave all hope those who enter here ${ }^{2}$. Despite numerous reforms and attempts to change the «prison traditions», we have the same prison world with its own «laws», to which the state has to adapt shamefully. And as long as the prison creates its own world of not social, specific, not human «criminal laws», faced with which everyone sees that the «stronger spirit» a criminal has the more valued he is and a greater degree of prison «ranks» he takes. No wonder that P. Kropotkin pointed out that till our prison does not realize the purpose of punishing repentance

2 Данте Алигьери. Божественная комедия. Москва: ЭКСМО, 2009. С. 34. 
and correcting criminals, it will forever remain «a university of crime kept at the expense of the state» ${ }^{3}$.

For centuries, hard labor, prisoner's labor and other prison trials, as a rule, turned prisoners into hardened criminals. For example, J. Mitford noted that even if the society tried to improve the conditions of the prisoners, not only the administration of institutions, but the other prison staff as well, opposed it in every way. She observes: specialists' attempts to carry out their mission faced opposition from the security departments with their «punitive approach to prisoners». The assimilation of punitive guidelines has negative consequences not only for convicts, but for personnel as well ${ }^{4}$.

The prison labor teams, camps and prisons of the Russian and Soviet period remain a terrible consequence for today. Despite the slogans that it can't be any victimization of the convicts, deliberate humiliation of their personal dignity, use of means of compulsory nature unforeseen by the law, there were significant violations of human rights in penal institutions and the respect and fair treatment to the convicts were rather an exception than a rule. Already in the 20's and 30's of the twentieth century the use of unskilled prisoners' labor on a royalty-free basis became the norm ${ }^{5}$. In various regions, especially in the Far East, the North, and then in all distant territories of the USSR, the corps-labor camps were organized in a hurry. Despite serious violations of law in Stalin's time, as it was noted by the scholars, politicians, writers and practitioners, great work concerning prisoners' correction through productive labor was done at the camps. For ethical reasons, we will not cite famous specialists who approved such labor use of convicts.

Pulling into the history of functioning of the corrective labor system, we remember how the talented and devoted architects, builders, constructors and writers made their achievements and discoveries in places of non-freedom. The notorious

\footnotetext{
${ }^{3}$ Kroptkin P. Les Prisons. Paris: Emile Nourry Editeur, 1880. C. 140.

${ }^{4}$ Mitford J. Kind and usual punishment. The Prison Business. New York. Alfred Knopf, 1975.

${ }^{5}$ Крахмальник Л. Г. Труд заключенных и его правовое регулирование в СССР. Саратов: Изд-во Саратовского университета, 1963. С. 15
} 
White Sea-Baltic, Volga-Don Canals, the building of the Baikal-Amur Mainline (BAM), wood fellings in the Komi Autonomous Republic, Perm Region, the Ivdelsky, Karelian and Magadan «spetslagi», building of a tunnel between the mainland and Sakhalin island. Everyone knows surnames of such academicians as S. P. Korolov, D. S. Lykhachev, others and their successes in rocket and aircraft construction, designing the best medium tank T-34 by M. I. Koshkin. It is on such persons as they were the economy of the state was rising and strengthening, but all mentioned happened in «prison» department. The cheap labor force of the prisoners and, as a result, $20 \%$ of gross national product were created by the corrective labor system of that time, and the enterprises of the system produced a fifth half of all the benefits that society enjoyed ${ }^{6}$.

Based on Marxist theory, specialists in Criminal and Executive (Correctional Labor) Law have, until recently, adapted to the idea that labor takes a special place among measures of correctional influence on convicts. This is due to the fact that the relation to socially useful activity is the highest ideological, political and moral criterion of a man. In their opinion, persons from convicts who do not have any labor skills, are not prepared for work psychologically, perceive methods of education poorly. Conducted theoretical researches and studying the practice of work of correctional institutions give grounds to affirm that labor during the period of imprisonment until recently was considered to be the main measure of convicts' correction. Today it is worth to realize that the use of free labor force, laborious, exhausting, unskilled labor is unlikely to be the basis for convicts' correction.

As the majority of scholars note, the recent totalitarian past of the country could not but influence domestic policy in the field of involving prisoners to labor, save the vices that are typical for Criminal and Executive System itself (further the CES). A heavy punishment imposed by the court that is imprisonment, often becomes unbearable in practice, deprives the convicts morally and, most often,

\footnotetext{
${ }^{6}$ Денисова Т. А. Покарання: кримінально-правовий, кримінологічний та кримінально-виконавчий аналіз: монографія. Запоріжжя: Вид-во КПУ, 2007. С. 231-237.
} 
physically (stomach ulcer, tuberculosis, accidents at work and in everyday life, nervous breakdowns, etc., are typical for those who are held in correctional institutions).

However, despite the fact that Ukraine has chosen democratic development, the idea that active counteraction to crime should be inextricably linked with the severity of the criminal law, the rigidity of the regime requirements, the obligatory use of convicts at hard, low paid jobs, etc., is dominant in social legal consciousness. Labor, as a correctional factor, is characterized from the point of view of general goodness of labor activity for individual and social development of a person. On the other hand, the voices are heard that there will be no disaster, if prisoners do not be occupied with labor. In order to convince the experience of foreign countries is given and it is stated that in most places of imprisonment convicts are not involved. Unfortunately, however, there are not clear parallels regarding the viability of the corrective labor potential on the background of unresolved social and disharmonious intentions of convict's personality, his internal alienation from social stereotypes of social interaction models. Let's try to understand these two opposing statements.

Experts rightly point out that according to Part 3 of Art. 43 of the Constitution of Ukraine ${ }^{7}$, the labor that is made by a person by a sentence or a court verdict, does not considered to be forced. And given that the court verdict does not involve the combination of imprisonment with convicts' obligatory work, if a man does not want to work and he is forced to do so in penal institution, then his work is forced. The legal basis for the use of socially useful labor are the principles of the norms of the CEC of Ukraine ${ }^{8}$ and the Labor Code of Ukraine ${ }^{9}$

\footnotetext{
${ }^{7}$ Конституція України: прийнята на п’ятій сесії Верховної Ради України 28 червня 1996 р. Київ: Преса України, 1997. С. 18-19.

${ }^{8}$ Кримінально-виконавчий кодекс України. Офіційний текст. Вид.: «ПАЛИВОДА А. В.». Київ, 2017.

${ }^{9}$ Кодекс законів про працю України. Редакція від 20 січня .2018 р., підстава 2249-19. URL: http://zakon3.rada.gov.ua/laws/show/322-08. Назва з екрану (дата звернення: 11.08.2018).
} 
At present, the issue of forced labor in penal institutions is less acute, because today, not everyone who wants to work can get a job, even what he does not like and what he does voluntarily. However, the belief that convicts' labor has the ability to change their personal qualities for better is rather stable. They are typical for domestic psychological and legal opinion.

It should be emphasized that the specifics of institutions where convicts serve sentences in Ukraine today does not allow them to be recruited based on their former specialty and individual characteristics. Manufacturing is usually lowskilled, and monotony, gray color of every day, the absence of prospects to change the work, limited communication, the inability to work according a specialty, and, at the same time, the lack of prospects of the received specialty in prisons, leads to the fact that labor does not have any corrective effect, but only becomes a burden and a necessary duty for the convicts. A man is a creator by his very nature and only the instinct of self-preservation helps them not to lose their creative spirit. Consequently, convicts look for at least some kind of exercise that will distract them from an ordinary life. Women begin to sew, to knit, men - to repair something in workshops, to draw and so on. As we see it, only radical changes in labor use, assistance in acquiring really useful skills that will help convicts not only in prisons but also after their release, in our opinion, would help the labor to perform corrective functions.

It seems that raising the level of productivity of convicts' labor should be carried out, first of all, by the expansion of activities. It requires appropriate refurbishment of production facilities, building of appropriate productive workshops, and, consequently, state lending. As professional researches shows, a man can change the attitude to work, and thus give a priority to it being at large rather than meeting material needs by committing a crime, if labor, as it was noted, enables a man to identify and to realize his creative abilities and skills. Consequently, the expansion of the types of labor activity will determine the need for studying, which should be focused on a convict's appropriate preferences. 
In our opinion, the organization of convicts' labor has a certain burden and therefore should meet the following requirements: work can be done according to quantitative and qualitative indicators, but it must be proportionate with physical and spiritual forces of a convict; it is gradually complicated in terms of production tasks in proportion to the acquisition of labor skills and the improvement of productive qualification; it represents not only creative but also material interest for the convicts. In labor use it is necessary to take into account the formation of positive motives of labor activity; expansion of professional interests; training of hard work and professional habits. The effectiveness of labor use of convicts depends not only on the content and equipment of production processes, but also on such conditions as: aesthetics of production; cleanliness of the rooms; forming of visual information; external cleanliness and so on. We also consider to be important the need for appropriate training of employees who train convicts and coordinate the production process.

It is believed that labor, according to the basic laws of human psychology, may have corrective or re-socializing, anti-criminogenic potential only in case of its voluntariness. If it is on the contrary, then it is considered to serve as a punitive means, without causing convict's respectful attitude and desire to work in future. The labor of convicts, in our opinion, serves as a fence against the degradation of an individual, which is likely through imprisonment.

An example of a transition from slave, unskilled labor can serve the experience of foreign countries. Fifty years ago, researchers of California Legislative Assembly published a report stating that the equipment of enterprises in most prisons was worn, masters did not have the appropriate qualification, and the labor industry barely achieved the goal of reducing idleness. The task of acquiring prisoners' skills to work, striving and desire to work was not fulfilled ${ }^{10}$.

Today, the situation in most developed Western countries has changed dramatically. Labor in Penitentiary Systems is represented not as a corrective but as

\footnotetext{
${ }^{10}$ Mitford J. Kind and usual punishment. The Prison Business. C. 228.
} 
an instrumental tool that enables convicts to live out the imprisonment more easily, gives an opportunity for those who wish to prepare for future freedom in terms of providing themselves with employment. Thus, the programs of labor employment of convicts in the Penitentiary System of Sweden are predetermined with a desire to achieve such an effect that individuals would work for their own pleasure, have an opportunity to get appropriate skills in a certain profession, through which it would be possible to ensure their existence in society and to prevent unlawful behavior. In addition to the productive workshops, the convicts are allowed to work according to those specialties that they had before sentencing and can continue distantly through the Internet (programming, accounting, management, etc.) that does not contradict the schedule of an institution ${ }^{11}$. Unfortunately, this possibility is not foreseen in Ukraine yet.

Convicts who are in the penitentiary institutions of France work in special workshops equipped in prisons. Labor activity, organized at their territory, is quite diverse: making of electronic devices; carpentry; producing of air conditioners; producing of aviation engines, etc. Measures have been taken in order to ensure the paid work for all wanted convicts as for the needs of the institution itself (in the dining room, laundry, shop, service of the institution), as in the productive workshops. In general, the French Penitentiary System employs around 9300 prisoners each year, receiving wages of around 37 million euro annually ${ }^{12}$.

Special attention should be paid at the experience of Germany. At the territory of Germany, prisons are divided into penitentiary institutions of open and closed types, as well as public and private ones. Partially privatized prisons in Germany are quite widespread. The labor of convicts is organized in workshops according to production tasks and can be both highly skilled and involving nonqualified people, with their further training. According to the results of such enter-

\footnotetext{
11 Денисова Т. А. Залучення засуджених до праці як засіб виправлення особи. Актуальні проблеми сучасної науки в дослідженнях молодих учених. Сімферополь: Таврія, 2006. Вип. 9. С. 124-130.

12 Ministère de la Justice [Електронний ресурc]. URL: http://www.justice.gouv.fr/_telechargement/dap/ plaquette_TRAVAIL_reedition_2012_opt.pdf. Назва з екрану (дата звернення: 11.08.2018).
} 
prises functioning, there has never been an incident that would lead to the loss of control over the management of this institution ${ }^{13}$.

The experience of Great Britain, Germany, France, Sweden, Finland has already been successfully handled by neighboring countries, in particular, by Latvia, Lithuania and Poland. As it seems, there is high time for researches in our country as well. After all, as it was rightly stated: the key to success lies in the overall moral value approach, ethics, transparency, the ability to see the prospects of activity, the prospects for convicts' re-socialization ${ }^{14}$.

Conclusions and offers. Becoming acute, the problem of protecting the interests of the society and an individual as a victim and as an offender as well, brings us to the need to rethink the views on the involvement of convicts into socially useful work. In the places of imprisonment, the development and expansion of the limits of professional orientation of a convict, who, after release, can use a profession that is useful both for the society and for a particular person, should be optimized.

We consider it absolutely necessary to study foreign experience of involving convicts in labor. As practice shows, there is a significant economic benefit and educational and corrective effect.

It is necessary to involve investors for building new institutions, including partially privatized, taking into account international requirements and standards. In order to avoid soviet mistakes, it is desirable to solve the problem of the possibility to serve sentences according to convicts' place of residence, including the creation of «mini-colonies» with productive workshops. Such institutions work successfully in Great Britain, where the main task is to create conditions for convicts that are closed to ordinary life.

\footnotetext{
${ }^{13}$ Нодар Лахути. Частные тюрьмы: как это работает. 24 октября 2013 г. [Электронный ресурс]. URL: https://pravo.ru/review/view/89878/. Название с экрана (дата звернення: 11.08.2018).

${ }^{14}$ La gestion déléguée des établissements pénitantiaires: 20 ans de partenariat public-privé. Min-istère de la Justice: Direction de l' administration pénitentiaire. Paris. 2015. 78 p.
} 
So, approaches of involving convicts in work, destructing conditions that cause an opportunity of creation of a slave, humiliating the honor and dignity of a person labor use, require radical changes. And the sooner practical implementation of such a reform will occur, the more people Ukraine will save from the criminal path.

\section{References}

1. Kroptkin P. Les Prisons. Paris: Emile Nourry Editeur, 1880. 239 c.

2. La gestion déléguée des établissements pénitantiaires: 20 ans de partenariat public-privé. Min-istère de la Justice: Direction de l'administration pénitentiaire. Paris. 2015. 78 p.

3. Ministère de la Justice [Електронний pecypc]. URL: http://www. justice.gouv.fr/_telechargement/dap/plaquette_TRAVAIL_reedition_2012_opt.pdf. Назва з екрану (дата звернення: 11.08.2018).

4. Mitford J. Kind and usual punishment. The Prison Business. New York. Alfred Knopf, 1975. 347 c.

5. Данте Алигьери. Божественная комедия. Москва: ЭКСМО, 2009. $544 \mathrm{c}$.

6. Денисова Т. А. Залучення засуджених до праці як засіб виправлення особи. Актуальні проблеми сучасної науки в дослідженнях молодих учених. Сімферополь: Таврія, 2006. Вип. 9. С. 124-130.

7. Денисова Т. А. Покарання: кримінально-правовий, кримінологічний та кримінально-виконавчий аналіз: монографія. Запоріжжя: Вид-во КПУ, 2007. $340 \mathrm{c}$.

8. Кодекс законів про працю України. Редакція від 20 січня .2018 р., підстава 2249-19. URL: http://zakon3.rada.gov.ua/laws/show/322-08. Назва з екрану (дата звернення: 11.08.2018).

9. Конституція України: прийнята на п’ятій сесії Верховної Ради України 28 червня 1996 р. Київ: Преса України, 1997. 80 с.

10. Крахмальник Л. Г. Труд заключенных и его правовое регулирование в СССР. Саратов: Изд-во Саратовского университета, 1963. 96 с.

11. Кримінально-виконавчий кодекс України. Офіційний текст. Вид.: «ПАЛИВОДА А. В.». Київ, 2017.

12. Нодар Лахути. Частные тюрьмы: как это работает. 24 октября 2013 г. [Электронный ресурс]. URL: https://pravo.ru/review/view/89878/. Haзвание с экрана (дата звернення: 11.08.2018). 


\section{Денисова Т. А., Крикушенко О. Г. Сучасні проблеми працевикористання засуджених до позбавлення волі \\ Авторами розглядаються основні питання правового регулювання пра-} ці в історії розвитку установ виконання покарань (виправних колоній), ї̈ місие в системі основних засобів виправлення та ресоціалізації. Визначаються проблеми, що виникають при залученні засуджених до суспільно корисної пращі в сучасних умовах функціонування виробництвв виправних колоній. Звертається увага на необхідність вивчення зарубіжного досвіду залучення засуджених до праці, оскільки в иььому вбачається істотна економічна вигода, виховний і виправний ефект. Вказані шляхи підвищення ефективності працевикористання засуджених в Україні на основі добровільності, розвитку і розширення меж професійної орієнтаџії засуджених, створення виробничих майстерень.

Ключові слова: засуджені, карально-виправний вплив, прачя, покарання.

\section{Денисова Т. А., Крикуиенко А. Г. Современные проблемы трудоиспользования осужденных к личению свободы}

Авторами рассматриваются основные вопросы правового регулирования труда в истории развития учреждений исполнения наказаний (исправительных колоний), его места в системе основных средств исправления и ресочиализачии осужденных. Определяются проблемы, возникающие при привлечении осужденных к общественно полезному труду в современных условиях функиионирования производств исправительныхх колоний. Обращается внимание на необходимость изучения зарубежного опыта привлечения осужденных к труду, поскольку в этом видится существенная экономическая выгода, воспитательный и исправительный эффект. Указаны пути повышения эффективности использования труда осужденных в Украине на основе добровольности, развития и расширения грании профессиональной ориентации осужденных, создания производственных мастерских.

Ключевые слова: осужденные, карательно-исправительное воздействие, труд, наказание. 